ECONOMIC THEMES (2020) 58(2): 203-217

DOI 10.2478/ethemes-2020-0012

\title{
INFLATION AND PRICES OF AGRICULTURAL PRODUCTS
}

\section{Nikola Njegovan}

University of Belgrade, Faculty of Economics, Republic of Serbia

$\bowtie$ nikolanj@ekof.bg.ac.rs

\section{Mirela Tomaš Simin}

University of Novi Sad, Faculty of Agriculture, Republic of Serbia

$\triangle$ mirela.tomas@polj.edu.rs

UDC

$336.748 .12+$

$338(497.11)$

Review

paper

Received:

29.01.2019

Accepted:

04.06.2020
Abstract: The stability of business in an economy has always been the primary goal that is difficult to achieve, and inflation is most often used as its basic indicator. It is a signal of change in the general price level. The paper analyzes inflation and prices of agricultural and food products as a combined phenomenon, examines their causes and consequences in the Republic of Serbia. Particular importance is attached to the change in prices of agri-food products and the prices of inputs caused by the changes that are taking place at the global level, which are gaining increasing influence in the national context. The change in price parity and the influence of the world monopolistic structure on inflation are pointed out. It also points to the importance of demand, which causes inflation in less developed countries, and which results in higher food prices, additionally putting pressure on wage growth, which, as a rule, is not a consequence of productivity growth. The authors state that with the internationalization of business activities, there was a transfer of influence of international trends on the level and effects of inflation at the national level. Given the trends in the world market, it can be concluded that the prices of agri-food products will not decrease. However, they will - due to the pressure exerted by the constant growth of the population, i.e. on the demand side, demand inflation will constantly manifest.

Keywords: inflation, prices, agricultural products, global perspective.

JEL classification: E00;E31 


\section{Introduction}

Inflation is a phenomenon that economists have been discussing for a long time. The term "inflation" itself was taken from the medical literature by the author A. Delmer, in his book from 1864: „A great paper deception or oncoming financial explosion" (Economic Encyclopedia, 1984 p. 839). The first inflation was defined exclusively as a monetary phenomenon. It describes a situation in which ,, too much money is chasing small amount of goods ". In contemporary conditions the issue of the cause of inflation is quite complicated. Some theorists (Musa \& Jun, 2020, Makin et al., 2017, He \& Zou, 2016) considered that the causes of inflation should be sought in excessive credit and stock market speculation, budget deficits, cheap money policy, unsecured bank credit policy and the war needs of the states. Observed exclusively from the monetary side, four main causes of inflation can be identified (Veličković and Barać, 2009): 1) inflation of effective cash demand purchasing power inflation, 2) inflation caused by disproportionate distribution of real national income, 3) inflation caused by reduction of commodity funds and 4) unfavorable movements in the balance of payments.

When it comes to the consequences that inflation has on the real economy and general economic conditions, they are numerous. In general, they are reflected in the general instability of the economic environment, which specifically means the distortion of relative prices in the economy, pressure on the exchange rate, lower real wages, higher interest rates on borrowing, higher government risk and many other implications. At the same time inflation is a phenomenon that negatively affects economic flows and also social trends.

Having agriculture in focus, it can be said that the international prices of agricultural commodities have exhibited a rising trend since the middle of last decade. The pace, as well as the magnitude of these increasing prices had not been experienced in recent history; it was last observed in the early 1970s. It is common knowledge now that international commodity prices are extremely volatile in nature and that booms and busts are relatively common occurrences in this market. A few incidents of sharp increase in commodity prices are dotted over the last century - the two such crucial periods being 1915-1917 (World War I) and 19731974 (first oil crisis) (Chakraborty, S., 2015). This upsurge in the agricultural commodity prices, especially those of food grains, has been a matter of major concerns for the global economy, in particular the developing one. Therefore, it becomes extremely important to analyze in details this phenomenon of rising prices in agricultural commodities.

In the case of the Republic of Serbia, it can be said that Serbia is in a position to permanently regulate the market situation with monetary measures since structural measures have been missing for decades in the scope that would be more significant. Thus, inflation in the previous three decades did not generally fall below $4 \%$, and at the end of the $20^{\text {th }}$ century, the high inflation rate was a record 
observed on the global - world scale.

The National Bank of Serbia has been conducting, since mid-2006, monetary policy through the inflation targeting regime, through the repo interest rate operations as a basic instrument. Targeting agreement inflation, signed by the Government of the Republic of Serbia and the National Bank of Serbia, means the formal transition of the National Bank of Serbia to inflation targeting as a monetary policy regime starting from 01.01.2009. The basic principles and functioning of this regime have been established by the Memorandum on targeting inflation as monetary strategy (Milanović et al, 2011).

Given the global trends in food prices, which, in the period from 2003 to 2011, increased by over $60 \%$ and their contribution to the general inflationary trends, both nationally and globally, the aim of this paper is to analyze the price policy in agrarian sector and the trends in agrarian prices globally.

\section{The essence of inflationary theories}

Beginning with the Great Depression in 1929, many economic schools changed their views on inflation in different ways. The differences were mainly conditioned by the priorities set at the macroeconomic level. In that sense, two schools stand out as dominant, not coincide in time, but each of them is conditioned by the economic and historical conditions of the time in which it was created. These are the so-called Keynesian and Monetarist school. They differ in the way they understand and interpret inflation and unemployment. Until the 1950s, the Keynesian school had a dominant influence in economics. It prioritized the requirement for full employment. This approach has been advocated by many economists, calling it the first-best solution, and they did not care much about inflation. However, since the 1950s, this concept has been in crisis, and it is "inherited" by a different point of view, a point of view in which inflation becomes a central category and everything is subordinated to it. Its value of $0 \%$ in this school becomes the first-best solution.

Contrary to Keynes's position, which was valid until inflation became a global economic problem, a point of view that respects and cares about inflation as a monetary phenomenon was gradually differentiated. One of the founders of this theory is the German economist Singer. He believed that inflation is manifested in the conditions of a significant increase in price levels which causes a sharp increase in the money supply. Similar to this view, other monetarists define inflation as a phenomenon that occurs when there is a disproportionate increase in money in circulation from what is needed, which results in a general rise in prices. Thus, the famous monetarist and Nobel laureate Milton Friedman, believes that inflation is always and everywhere a monetary phenomenon, and that it occurs with the growth of the amount of money faster than the growth rate of production. He believes that 
there is no such stable empirical connection between economic phenomena that is based on so much tangible evidence, as is the case with the connection between major changes in the amount of money and changes in the price level. As a remedy, he recommends a restrictive monetary policy, i.e. reducing the amount of money in circulation to a harmonious attitude towards the movement of production. In his opinion, short-term inflation helps economic growth and employment. In contrast, neo-Keynesians believed that inflation was not a monetary phenomenon. Hence the controversies on the topic of inflation that reach the present day, when the world economy is on the verge of stagflation or possibly a deeper economic crisis (Stojanov, 2008: 55). Hence, in connection with that, there are intensive discussions about the effects of monetary policy and its impact on the level of prices and employment.

When it comes to fighting inflation, the Keynesians approach advocates an active role for the state. In conditions of insufficient aggregate demand, an approach to the policy of state investments and reduction of tax revenues is suggested. Tax reduction usually refers to low and middle income groups, whose share in total budget revenues is relatively modest (Pejanović, 2008: 23). This can be applied when it comes to the short term, but when it comes to a longer period of time, this approach has proven to be inadequate, because it negatively affects the growth of production and employment, and raises the inflation rate. On the other hand, the neoclassical approach relies on credit - monetary policy. It is considered that inflation is a consequence of the increase in the money supply, and that the Central Bank plays an important role in that sense, given that it is in charge of placing the money supply. Therefore, the Neoclassicists advocate that the Central Bank should intervene in the interest rate segment (bearing in mind the inflation rate). Thus, it can be concluded that anti-inflation policy distinguishes long-term and short-term approaches. When a country pursues a long-term anti-inflationary policy, it strives to support the efficient functioning of the market; then, it controls the money supply; and strives to optimally address the budget deficit. In the case of a short-term anti-inflation policy, the basic goal is, certainly, to reduce inflation immediately by giving incentives to production from the funds held.

\section{Price policy in the agrarian sector}

When it comes to inflation, prices are definitely an unavoidable, even central topic. The most common topic is the so-called nominal prices as an element of individual or overall balance. These prices are associated with the so-called normal income. The analysis of market prices is based on the following assumptions: the presence of complete competition, the homogeneity of products within the industry, the complete mobility of capital and the capitalist mode of production. Hence the critique of both supply and demand as price determinants is basically based on a critique of the origin of the commodity value. Price theories in the so-called market 
economies start from the viewpoint that normal prices are formed under the influence of supply and demand forces. They consider that behind the supply are the average costs, and behind the demand the subjective perception of the value of the good, that is, their marginal benefit and income. The normal price equilibrium is derived from the balance on the side of the bidders and consumers. However, the theory of limited competition is based on a monopoly price in which the monopolist, besides normal, also generates extra income because the ability to manipulate with demand and supply. Hence, it should be pointed out that the socalled market economies theory has made a significant contribution in explaining the equilibrium price phenomenon observed in different market structures. It is reflected in the research of the connection between price and demand (price elasticity), the price interaction (cross-elasticity) and the dependence of the price equilibrium on the social productivity of labor (normal price with rising, declining and constant costs), that is, the impact of social productivity on price formation in branches with increased, above-average and sub-average social productivity of labor.

The policy of prices of agricultural food products is an integral part of the agrarian policy in each country. Price is the basic factor that determines the business conditions and financial position of agrarian entities in the primary distribution. For that reason, each country strives to define a price intervention system that is in line with agricultural development policy. Optimally defined price parities should affect the stability and profitability of primary agricultural production. Thus, producers are motivated to increase the volume and quality of production.

Prices of agrarian products can be characterized as the prices of the necessary society product. They influence not only the real incomes of agricultural producers, but also the level of accumulation of consumers and producers in non-agricultural activities (Chandrasekhar C.P., 2013). Agricultural prices are, also, defined as extremely volatile (Bodhanwala et al, 2020). If the prices of agrarian products are higher, it is necessary to allocate most of the income for food, and consequently, the smaller part remains to meet other needs. However, on the other hand, it should be pointed out that prices cannot be defined as a universal instrument for influencing agricultural producers, including prices that are expressed on the international market. In addition, the orientation of agrarian production and its structure are influenced by loans, various subsidies, premiums, reliefs, tax and contribution exemptions, and so on.

The influence of the prices of agricultural products on the inflation have macroeconomic (viewed from the social community position) and microeconomic aspect (viewed from an individual or household position). 


\subsection{Macroeconomic perspective}

The ability of agrarian policy to address above mentioned issues is, in addition to other activities, somewhat narrowed and difficult. First of all, because the necessary resources for agrarian production are limited (fixes production capacity which practically means that supply side is conditionally limited) are reduced day by day. This should be added to the fact that agrarian production is of a biological nature and it is affected by a whole series of natural conditions (which can be relatively controlled nowadays). It is also important to mention that this production is typical seasonal production. On the other hand, the rise in food and energy prices is no longer a transient phenomenon bound only to national frameworks (Huria \& Pathania, 2018). Some believe (Arnade et al., 2017, Choi \& Entenmann, 2019, that there is a complex change in the price ratio on the world market. Hence, the rise in food and energy prices can no longer be seen as a reflection of short-term disorders (McFarlane, I., 2016). The high demand for raw materials, food and energy coming from developing countries, as well as countries such as China and India, significantly influence the long-term nature of these processes. In addition, with food prices on the supply side, the situation is further complicated. Arable land is increasingly used for the production of biofuels and along with population growth, there is a decrease in arable land for food production. Therefore, today, the leveling of the prices of agricultural and food products have decisive influence on inflation, as they have a direct impact on the household budget.

This has greatly influenced the way inflation has been calculated since the 1990 s and the new way of conducting monetary policy. Since then, It has relied on the so-called "targeted inflation". However, in the meantime, this system of calculating inflation has been seriously questioned, primarily due to the permanent rise in food and energy prices. Such a system of calculation was once made official by the European Union, which was later accepted by the Republic of Serbia ${ }^{1}$. This methodology has not neglected the impact of petroleum product prices. According to this calculation system, this influence was incorporated into the price of agricultural and food products.

The quintessence of this whole topic, observed from the macroeconomic point of view, is that agriculture is an activity of the economy that provides food for the population. „The amount of the so-called market surpluses, i.e. the amount of food produced that is not consumed in the agricultural sector, but can be used in other sectors. The increase of these surpluses over time is necessary, first as an indicator of increased productivity in agriculture, and secondly, to feed workers in industry and other sectors with cheap food, which is the basis for maintaining relatively low wages" ${ }^{2}$. Consequently, if the price of agricultural products is high, then there is an

\footnotetext{
${ }^{1}$ Namely, in 2009, Serbia introduced this system of calculating inflation for the first time, and from this year it is possible to make a comparison with other members of the European Union.

${ }^{2}$ For more details, see: Njegovan Z., M., "Economic Systems", Belgrade, 2009, p. 66 - 67.
} 
increase in wages in the industrial sector (raising wages is unjustified because there has been no increase in productivity). This increase in wages represents an additional cost and the implication of the increase in costs is less competitiveness in the foreign market (so this leads to a decrease in foreign exchange inflows). In addition, an unjustified increase in wages will inevitably cause inflation as a result of rising demand for agri-food products, while the supply of agricultural food products is relatively limited.

The goal of any macroeconomic policy is strong agriculture, but not agriculture which should be the "locomotive of development". It should only be a good base, while development should be based on the accelerated development of industry (Luis A., 1954). So, without strong agriculture, there is no strong industry, while the opposite is not possible ${ }^{3}$.

\subsection{Microeconomic perspective}

The production of agricultural products is the basis of the agrarian enterprises' activities on one side, and the nutrition of individuals on the other side. Prices of these products represent a regulative factor of their quantitative and qualitative consumption. Experience indicates that if food expenditures are $30 \%$ and more of available family income, this is an indicator that something is wrong with economic and political conditions in the country. This is illustrated by the structure of personal consumption in Serbia, Graph 1. The data shows that Serbia is in the category of underdeveloped countries, given that the relative share of basic agricultural food products is slightly more than one third of the total available funds of family budgets. Under such conditions, an increase in wages that is not accompanied by an increase in productivity creates additional pressure on inflation growth.

Hence, it can rightly be said that the impact of agricultural and food prices on inflation is both macroeconomic (socio-economic) and microeconomic (affecting households themselves).

\footnotetext{
${ }^{3}$ An example of Japan, which after the Second World War first invested in agriculture and later in the industry. The time period needed for the industry to take the primacy, in this case, was about ten years (since 1965 the industry has recorded higher economic growth).
} 
Graph 1: The structure of personal consumption in Serbia (in \% for 2019)

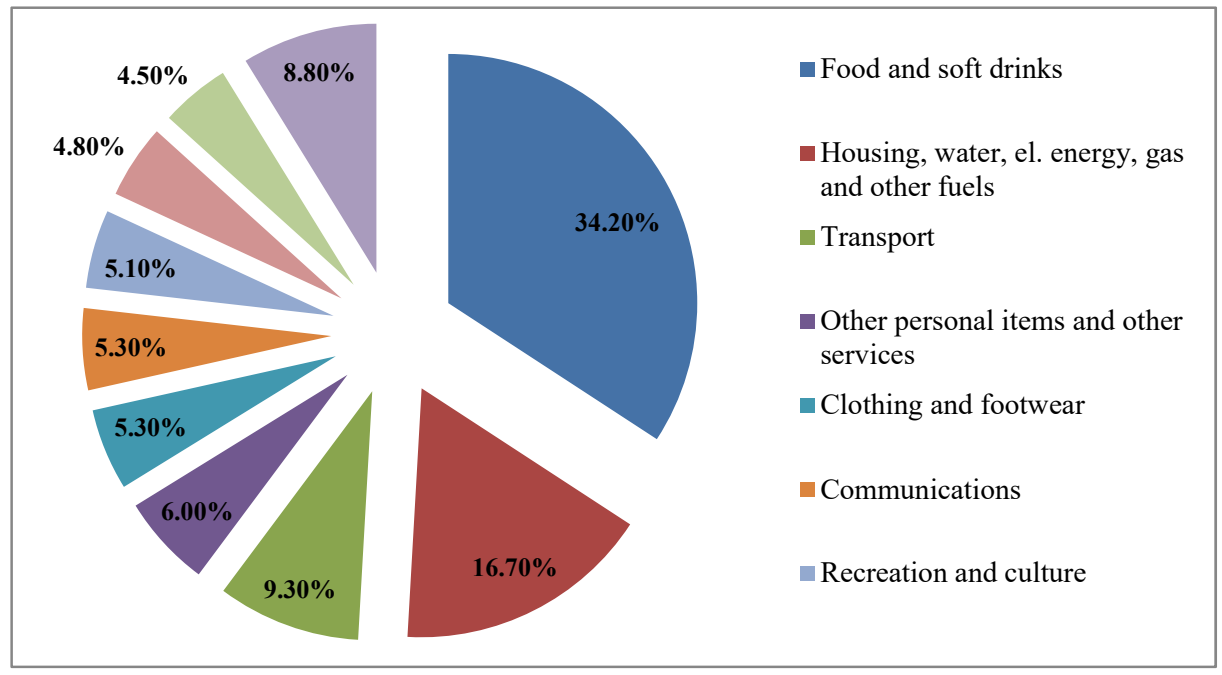

Source: Statistical Office of the Republic of Serbia, Survey on Population Consumption.

\section{Prices of agricultural products, input prices and global prospects}

Before anything is said about the impact factors on the prices of agricultural food products, the importance of availability or the limitations of the land resources should be emphasized. It fixes the production capacity of agriculture, that is the supply side. On the other hand, there is a pressure caused by population growth, as well as the impact of natural conditions, seasonal character and alike. All of these factors, put together, have a significant impact on the prices of agricultural and food products. But today importance of another factor - the factor of the international market, is also growing.

\subsection{Price movements of agrarian products on the international market}

The international market is, in most cases, the objectively determined factor of agrarian prices in each country. It arises as a result of conditions dictated by the process of globalization of production, financial and technological flows. There is also the influence of the monopolistic structure of the world market. It is a consequence of capital appreciation and the creation of ,big players" that take the dominant position in the market and act monopolistic in terms of their share on the market. Also, the factor of strengthening the integration of country under the influence and control of strong (economically powerful) countries should be stated. Beside the stated, the important factors that additionally affect the prices movement 
of agrarian products are the following: the increase in demand for agrarian products in developing countries, higher prices of fuels and basic assets necessary for agricultural production, higher transport costs, specificity of agricultural production which is reflected in the influence of natural factors, the reorientation of food crops for alternative production (biofuels, etc.), and the introduction of a policy on restricting food exports by some countries, etc.

In contemporary conditions price oscillation of agricultural products is largely realized under the influence of increased demand for raw materials that are processed by renewable energy sources (Mitchell, 2008 p. 7). In addition, some authors argue that an important factor is the expansive monetary policy that occurs in industrialized countries (Frankel, 2006 p. 22; Krichene, 2008 p. 356). Hence, it is considered that the time of low-cost foods has passed. This is indicated by changes in the movement of prices of agricultural products and food, Graph 2.

Graph 2: Movement of prices of agrarian products and food on the world market

$(2010=100)$

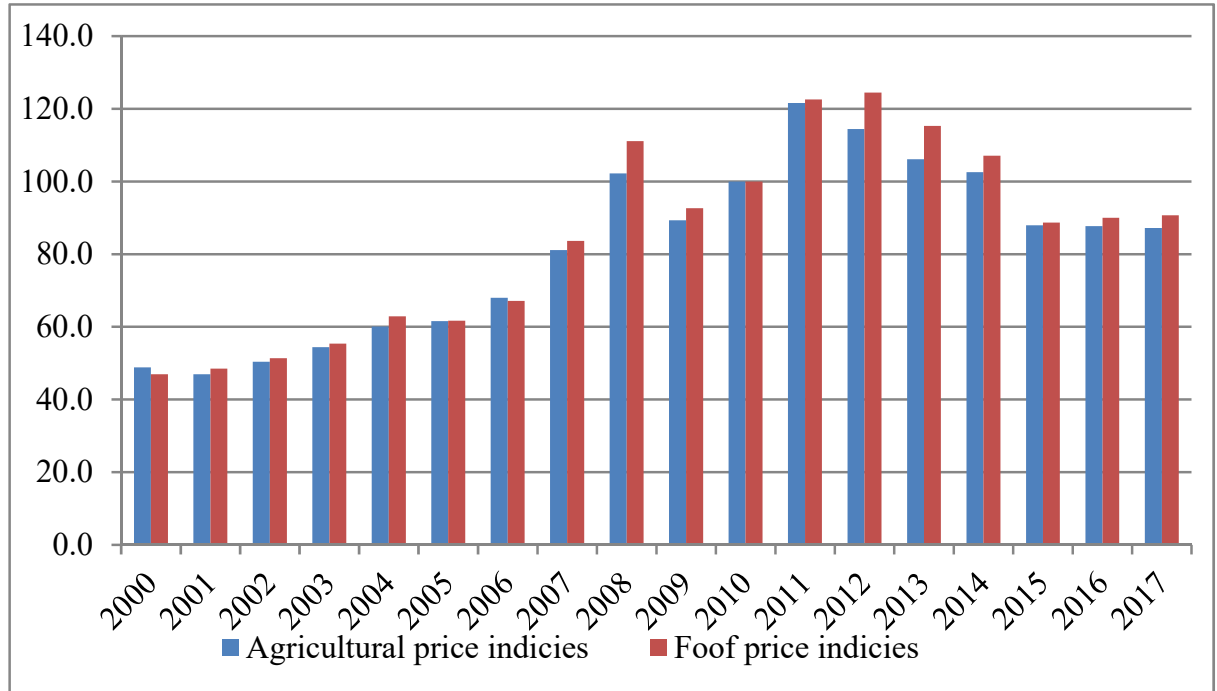

Source: World Bank Commodity data.

As the most important there is an increase in the price of crops. In the last decades they have increased four times on the global level (Pejanović \& Njegovan, 2009 p. 95). Hence, an effective national agricultural policy should have in mind two important determinants: firstly, the jump in prices of agricultural products on the international market will affect national prices and, therefore, inflation; and second, there is also an impact based on the expectation of future food price movements, which is why pressure on wage increases begins. 
All this leads to a rise in core inflation. In many countries and regions, situations in which food price increases are higher than aggregate inflation contribute significantly to inflationary pressure. For example, in Europe and Central Asia, in 2007 total inflation was only $10 \%$ before the crisis (2008), food prices inflation was as high as $15 \%$, while inflation of bread and grain prices was as high as $23 \%$ (Alam \& Vybornaia, 2008 p. 188).

\subsection{Movement of input prices}

Changes in the prices of agricultural products can also be explained by the change in the price of inputs, primarily energy sources ( $\mathrm{Su}$ et al., 2019), Graph 3. This is why the issue of food production and demand is directly dependent on energy supply opportunities in the long-term approach. Therefore, it can be said that energy and food are factors that substantially define the inflation rate.

The global economic crisis of 2008 led to further redistribution of economic power on a global scale. The main economic indicators point out that the relative economic significance of the USA, Japan and the EU has declined, and the position of developing countries is stronger, in particular the energy export and BRICS countries (Brazil, Russia, India, China and the Republic of South Africa).

\section{Graph 3: Trends in crude oil prices (1990-2020) US \$ / barrel}

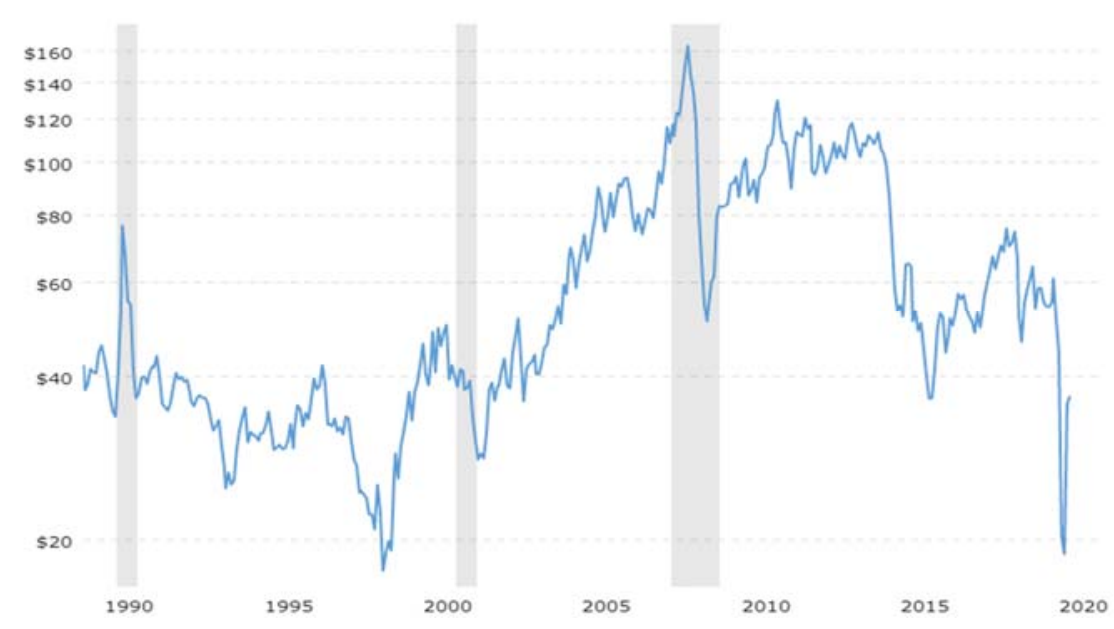

Source: Statistical office of the European Union (www.ec.europa.eu)

In the case of the Republic of Serbia, as one of the underdeveloped countries, there has been a significant deterioration of the parity of agricultural product prices according to input prices. An example of wheat as one of the vital products and changes that occurred in the parities during the economic crisis of 2008 can be pointed out, Graphs 4 and 5. 
Graph 4 and 5: Change in the parity of prices of basic inputs and prices of wheat in the Republic of Serbia

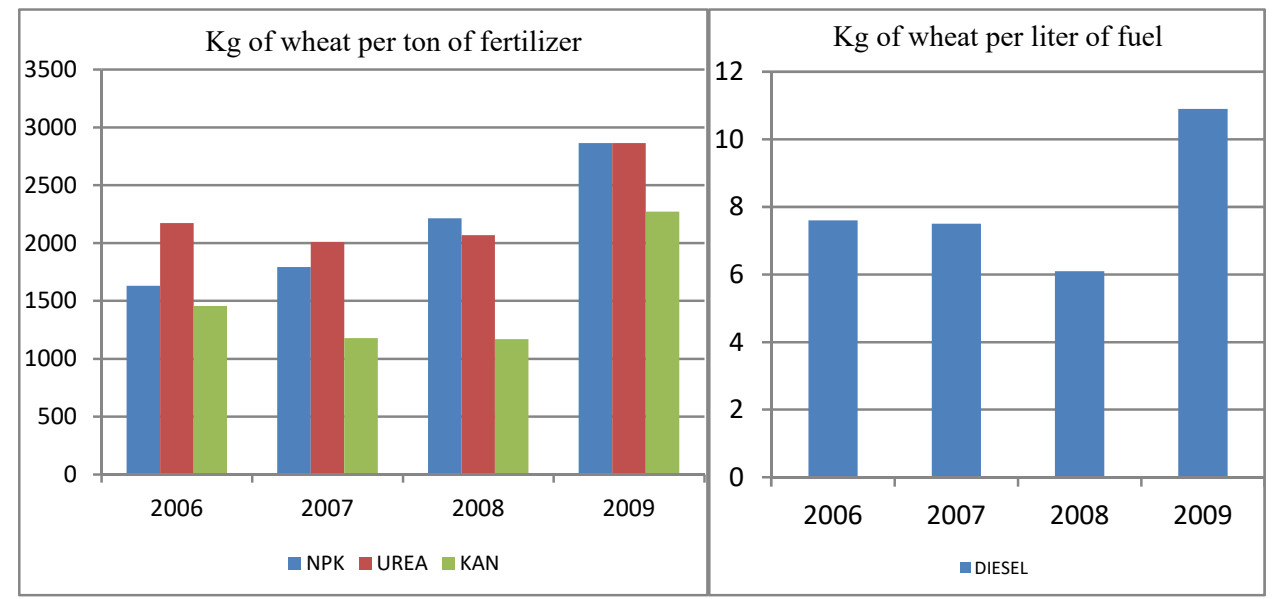

Source: Chamber of Commerce of Vojvodina, Statistical Office of the Republic of Serbia and authors' calculation

The opinion of the authors is, and the World Bank also forecasts, that in the upcoming period the tendency of food prices fluctuations will continue, due to many global and internal factors in certain countries. Estimates are that by 2050 , the demand for food will increase between $70-100 \%$, compared to 2010 . On the other hand, the growth of agrarian production by 2020 is estimated at an average of $1.7 \%$ per year, which is a decrease of $2.6 \%$ compared to the previous decade (FAO, 2016).

The question arises: how is the maneuvering space of the Central Banks of individual countries in meeting the targeted inflation? Because, in the conditions of the underdeveloped market mechanism, the lack of discipline in the fiscal and financial part, the lack of a clearly differentiated structural policy in the real sector (these are the features of the economy of the Republic of Serbia), it is obvious that only monetary measures can achieve the stability of prices in the long time limit. In this respect, the quantity of the so-called market surplus food is important. Their growth is necessary, first as an indicator of an increase in productivity in agriculture, and secondly, for the purpose of meeting the needs of workers in industry and other sectors for low-cost food, which is the basis for maintaining relatively low wages (Njegovan et al., 2009 p. 66-67). The high demand for raw materials, food and energy coming from countries with dynamic development, especially from China and India, additionally influence on these processes. It is estimated that there is a reciprocal influence, that is, that inflation has a decisive influence on the leveling of prices of agricultural products. 


\section{Conclusion}

The question of inflation, its causes and consequences, is continuously taking over not only the economists of the developed and underdeveloped world, but also those involved in the economy, especially in raw materials brunches such as agriculture. The question of inflation is important for the success of the business as well as the existence of each individual.

Some of the important factors influencing the level of inflation are the prices of agricultural products, but also the price of inputs that participate in agricultural production. It can be concluded that with the internationalization of business activities there has been a transfer of the influence of international trends on the level and effects of inflation at the national level. In this sense, sometimes the possibilities of national agrarian policy are partially narrowed in terms of controlling the mentioned prices, and therefore also inflation.

Inflation is not only a monetary category, so it cannot be controlled only by monetary policy measures. A monopolistic structure of the world (agro)economy and the presence of the so-called „big players“ also have significant influence on inflation. A similar effect is caused by the development of the integration of countries and their impact on the movement of input prices and the prices of agricultural and food products.

Considering the trends in the world market, it can be concluded that the prices of agricultural food products will not decrease. Due to the pressure of constant population growth, on the demand side, there will be a constant rise in demand inflation.

The current situation and problems that characterize Serbian agriculture and rural areas make it difficult to deal with global challenges, among other things, because the Serbian agrarian sector is under the strong influence of European

highly competitive agriculture.

\section{References}

Alam, K. \& Vybornaia, M. (2008). Rising Food Grains and Energy Price. sin ECA: Some Economic and Poverty Implications, and Policy Responses, UK.

Arnade, C., Cooke, B., \& Gale, F. (2017). Agricultural price transmission: China relationships with world commodity markets. Journal of Commodity Markets, 7, 28-40.

Avramović, D. (2007). Rekonstrukcija monetarnog sistema. ECPD, Beograd.

Bodhanwala, S., Purohit, H., \& Choudhary, N. (2020). The causal dynamics in Indian agriculture commodity prices and macro-economic variables in the presence of a structural break. Global Business Review, 21(1), 241-261.

Chakraborty, S. (2015). Explaining the rise in agricultural prices: Impact of neoliberal policies on the agrarian economy. Agrarian South: Journal of Political Economy, 4(2), 232258 . 
Chandrasekhar, C. P. (2013). Not a benign market: An analysis of food price inflation and volatility. Agrarian South: Journal of Political Economy, 2(2), 121-159.

Choi, H. S., \& Entenmann, S. K. (2019). Land in the EU for perennial biomass crops from freed-up agricultural land: A sensitivity analysis considering yields, diet, market liberalization and world food prices. Land use policy, 82, 292-306.

Đukić M., Momčilović, J., \& Trajčev, Lj. (2010). Model za srednjoročne projekcije Narodne banke Srbije, Stručni radovi NBS, br. 1, str 17-41.

Ekonomka enciklopedija (1984), Savremena administracija, Beograd.

Food and Agriculture Organizacion - FAO (2016). Growing demand on agriculture and rising prices of commodities, www.ifad.org/events/gc/31/roundtable/food.pdf

Frankel, J. (2006). The Effects of Monetary Policy on Real Commodity Prices, NBER Working Paper 12713 USA.

He, Q., \& Zou, H. F. (2016). Does inflation cause growth in the reform-era China? Theory and evidence. International Review of Economics \& Finance, 45, 470-484.

Huria, S., \& Pathania, K. (2018). Dynamics of Food Inflation: Assessing the Role of Intermediaries. Global Business Review, 19(5), 1363-1378.

Hutchison, W., (1981). The politics and philosophy of economics, Basil Blackwell.

Indeks potrošačkih cena, Metodološki materijal, Republički zavod za Statistiku.

Izveštaji NBS o tromesečnom kretanju inflacije u Republici Srbiji (2000- 2017), internet stranica www.nbs.rs.

Keynes, J. M. (1956). Opšta teorija zaposlenosti, kamate i novca, Kultura, Beograd.

Krichene, N., (2008). Recent Inflationary Trends in World Commodities Markets, IMF Working Paper USA.

Lewis, W. A. (1954). Economic Development with Unlimited Supplies of Labour. The Manchester School, 22, n. 2: 139-191.

Makin, A. J., Robson, A., \& Ratnasiri, S. (2017). Missing money found causing Australia's inflation. Economic Modelling, 66, 156-162.

Marinković, S. \& Radojičić J. (2009). Inflation targeting challenged by financial crisis, Economics and Organization 6(3): 237-250.

McFarlane, I. (2016). Agricultural commodity prices and oil prices: Mutual causation. Outlook on Agriculture, 45(2), 87-93. https://doi.org/10.1177/0030727016649809

Milanović, M., Ljubić, M., \& Muminović, S. (2011). Uticaj cena hrane na ciljanu inflaciju u Republici Srbiji. Ekonomika poljoprivrede, 58(4), 547-562.

Mitchell, D. (2008). A note on rising food prices. World Bank Policy Research Working Paper 4682 USA.

Musa, U., \& Jun, W. (2020). Does inflation targeting cause financial instability?: An empirical test of paradox of credibility hypothesis. The North American Journal of Economics and Finance, 52(C).

Narodna banka Srbije, Memorandum Narodne banke Srbije o utvrđivanju ciljane stope inflacije za period od 2010-2012. godine.

Njegovan, Z., Filipović, M., \& Pejanović, R. (2009). Privredni sistem, politika i razvoj, Poljoprivredni fakultet, Novi Sad.

Pejanović, R. \& Njegovan, Z. (2009). Aktuelni problemi poljoprivrede i sela R. Srbije, Industrija br. 1, Beograd, str. 87-99.

Stojanov, D. (2008). Kontraverze o inflaciji: da li je inflacija od 0\% moguća i korisna?, Ekonomija, br.2 str. 387-407, Hratska internet stranica www.rifin.com (pristupnjeno 24.7.2017.). 
Su, C. W., Wang, X. Q., Tao, R., \& Oana-Ramona, L. (2019). Do oil prices drive agricultural commodity prices? Further evidence in a global bio-energy context. Energy, 172, 691701.

Veličković D. \& Barać S. (2009). Makroekonomija. Univerzitet Singidunum. Beograd.

World Bank Commodity data 2006-2017.

\section{INFLACIJA I CENE POLJOPRIVREDNIH PROIZVODA}

Apstrakt: Stabilnost poslovanja u ekonomiji je uvek bila glavni cilj koji je teško postići, a inflacija se najčešce koristi kao njen osnovni pokazatelj. To ukazuje na promenu opšteg nivoa cena. U radu se analizira inflacija i cene poljoprivrednih i prehrambenih proizvoda kao objedinjeni fenomen, ispituju njihovi uzroci i posledice u Republici Srbiji. Poseban značaj se pridaje promeni cena poljoprivredno-prehrambenih proizvoda i cena inputa izazvanih promenama koje se dešavaju na globalnom nivou i koje dobijaju sve veći uticaj u nacionalnom kontekstu. Ukazano je na promenu pariteta cena i uticaj svetske monopolističke strukture na inflaciju. Takođe se ukazuje na značaj tražnje, koja izaziva inflaciju u manje razvijenim zemljama, što se odražava na višu cenu hrane, dodatno vršeći pritisak na rast plata, što po pravilu nije posledica rasta produktivnosti. Autori navode da je internacionalizacijom poslovnih aktivnosti došlo do prenosa uticaja međunarodnih trendova na nivo i efekte inflacije na nacionalnom nivou. S obzirom na trendove na svetskom tržištu, može se zaključiti da cene poljoprivrednoprehrambenih proizvoda neće opadati, već ce se, između ostalog, usled pritiska koji vrši stalni rast stanovništva, tj. sa strane tražnje, porast tražnje stalno manifestovati.

Ključne reči: inflacija, cene, poljoprivredni proizvodi, globalna perspektiva

\section{Acknowledgement}

The paper is part of the research on project contract no 451-03-68/2020-14/ 200117, financed by the Ministry of Education, Science and Technological Development of the Republic of Serbia. 


\section{Authors' biographies}

Nikola Njegovan, PhD, Assistant Professor at the Faculty of Economics, University of Belgrade. He was born on November 3, 2005 year. He graduated from the Faculty of Economics in Belgrade in 2008 with an average grade of 9.25 (in direction of economic analysis and politics). At the same faculty in cooperation with the University of Nice (France), he enrolled in the master course: "Macroeconomics of the Economies in Transition", with an average grade of 9.5 and defended the master's work: "Testing the validity of the theory of effective wage on the example of EU countries - 25 ". At the same Faculty he enrolled doctoral studies at the module "Economics" (subject: the theory of monopolistic competition and welfare analysis.) He passed all exams with an average grade of 10 , and registered and defended his doctoral dissertation: "Limited rationality in the theory of monopolistic competition". After completing basic studies, he worked for several years as a demonstrator on the subject "Price theory" at the Faculty of Economics in Belgrade. In a short period of time he worked as a trainee at the Institute of Agricultural Economics in Belgrade. In 2011 he became an assistant and then assistant professor in subjects "Price theory" and "Microeconomic analysis". He has published several scientific and professional papers independently and in co-authorship as well participated at conferences in the country and abroad. His basic area of interest are the theory of monopolistic competition and the labor market.

Mirela Tomaš Simin, PhD, Assistant Professor at the Faculty of Agriculture, University of Novi Sad. She was born on May 26, 1982 in Vršac. She finished bachelor, master and $\mathrm{PhD}$ studies at the Agricultural Faculty of the University of Novi Sad, Department of Agroeconomics. As an Assistant Professor she is engaged in several courses - Microeconomics, Macroeconomics, Principles of Economics and Economics of Tourism. So far, she has been engaged in a number of international projects, projects funded by the Ministry of Education, Science and Technological Development of the Republic of Serbia, as well as several projects financed by the Provincial Secretariat of APV. Her professional interest is related to the fields of organic agriculture, sustainable economic development and agriculture economics and agricultural policy. She is the author and co-author of several scientific publications and a one monograph. She is a member of the Scientific Society of Agricultural Economists of the Balkans, the Center for Agrarian History and a member of the Administrative Board of the Vojvodina Cluster for Organic Agriculture. 